\title{
Trichoderma asperellum and rhizobacteria improving biomass accumulation and gas exchange of lowland rice
}

\author{
Israel Mendes Sousa ${ }^{1}$, Adriano Stephan Nascente ${ }^{2}$, Marta Cristina Corsi de Filippi ${ }^{2}$, Anna Cristina Lanna ${ }^{2}$ \\ ${ }^{1}$ Universidade Federal de Goiás - UFG, GO. ${ }^{2}$ Embrapa Arroz e Feijão, Santo Antônio de Goiás, GO. E-mail: \\ israelmmendes128@gmail.com
}

\begin{abstract}
Rice the main source of energy to maintain the metabolism for almost four billion people worldwide. Rice plants treated with multifunctional microorganisms may be a good way for sustainable improvement of crop grain yield. Aimed study the effect of types and ways of microorganisms application in tropical lowland rice production, evaluated by biomass production and gas exchange. The greenhouse trial was in a completely randomized design, in factorial scheme $7 \times 3+1$, with four replication. Treatments were the combination of seven microorganisms: Bacillus sp. (BRM32109 e BRM32110); Pseudomonas fluorescens (BRM32111); Pseudomonas sp. (BRM32112); Burkholderia pyrrocinia (BRM32113); Serratia sp. (BRM32114) and Trichoderma asperellum pool (UFRA.T06 + UFRA.T09 + UFRA.T12 + UFRA.T52), with three forms of application (1. microbiolized seed; 2 . microbiolized seed + soil drenched with microorganism at eight and 15 days after sowing (DAS) and 3. microbiolized seed + microorganism spray plant at eight and 15 DAS). Microbiolized seed was the best form of application, which allowed highest instantaneous carboxylation efficiency and yield of biomass production in lowland rice. Rhizobcteria BRM32114, followed by BRM32111, BRM32112 and fungi T. asperellum improved, an average, 17\% in instantaneous carboxylation efficiency and $20 \%$ in dry shoot biomass production of lowland rice compared to the control plants.

Keywords: association of microorganisms and rice; Oryza sativa; plant growth promoting rhizobacteria; sustainable development.
\end{abstract}

Thichoderma asperellum e rizobactérias melhorando o acúmulo de biomassa e trocas gasosas em arroz irrigado

\section{Resumo}

Arroz é a principal fonte de energia para manutenção do metabolismo de quase quarto bilhões de pessoas no mundo todo. Plantas de arroz tratadas com microrganismos multifuncionais pode ser uma boa maneira para melhoria sustentável do rendimento de grãos. Objetivou-se estudar o efeito de tipos e formas de aplicação de microrganismos na produção de arroz irrigado tropical, avaliado pela produção de biomassa e trocas gasosas. Ensaio em casa de vegetação foi realizado em delineamento inteiramente casualizado, no esquema fatorial $7 \times 3+1$, com quatro repetições. Tratamentos consistiram da combinação de sete microrganismos: Bacillus sp. (BRM32109 e BRM32110); Pseudomonas fluorescens (BRM32111); Pseudomonas sp. (BRM32112); Burkholderia pyrrocinia (BRM32113); Serratia sp. (BRM32114) e Trichoderma asperellum pool (UFRA.T06 + UFRA.T09 + UFRA.T12 + UFRA.T52), com três formas de aplicação (1. semente microbiolizada; 2 . semente microbiolizada + solo inundado com os microrganismos aos oito e 15 dias após a semeadura (DAS); e 3. semente microbiolizada + pulverização dos microrganismos nas plantas aos oito e 15 DAS). Microbiolização de sementes foi a melhor forma de aplicação dos microrganismos, o qual promoveu a maior taxa de eficiência instantânea de carboxilação e rendimento da produção de biomassa em arroz irrigado. Rizobactéria BRM32114, seguido por BRM32111, BRM32112 e fungo T. asperellum aumentaram, em média, $17 \%$ na eficiência instantânea de carboxilação e, $20 \%$ na produção de biomassa seca da parte aérea de arroz irrigado comparado com plantas controle. 
Palavras-chave: associação de microrganismos e arroz; Oryza sativa; rizobactérias promotoras de crescimento em plantas; desenvolvimento sustentável.

\section{Introduction}

Rice (Oryza sativa L.) is the staple food of half of world population. These people largely depend on rice for caloric supply and nutrition, consuming, at least, $715 \mathrm{kcal}_{\text {capita }}{ }^{-1}$ day $^{-1}$. Beside, its grains supply, in developing countries, $27 \%$ of dietary energy, around $20 \%$ of dietary protein and $3 \%$ of dietary fat. Thus, it's one of the most important cereals produced worldwide (BORÉM; RANGEL, 2015; SEN et al., 2020). In 2019 were produced 755.5 million of rice tons in the world (FAOSTAT, 2021), and, its corresponded to the $3^{\text {rd }}$ position on ranking of cereal crop harvest. Only corn and wheat had higher production than rice. In Brazil, the total planted area is approximately 1.7 million hectares, with 10.9 million of tons production (CONAB, 2021).

Demand for food is increasing year by year, thus, food production could be increased to avoid the gaps between global food demand and supply (TIAN et al., 2021). However, one of the main concerns to increase food production is the high uses of hazardous pesticides and synthetic fertilizers, which is not sustainable and provoke damage to the environment (SAHA; BAUDDH, 2020). Therefore, it is important to develop technologies to improve food production in a sustainable way. The use of multifunctional microorganisms is a good strategy and its use enhances worldwide (GHOLAMALIZADEH et al., 2017).

On rhizosphere region - few millimeters where there is contact between soil and plant roots - pathogenic and non-pathogenic microorganisms, such as fungi, bacterial, virus and nematodes, inhabit and interact between them. Plant growth promoting rhizobacteria (PGPR) is an example of non-pathogenic microorganisms that interact with plants on the rhizosphere region. PGPR are multifunctional microorganisms able to colonize root systems of plants and promoting its growth and development with direct and indirect mechanisms (KLOEPPER; SCHROTH, 1978). Directly, PGPR acts in hormones production, which are able of promote elongation of root system (SPENCE et al., 2014), can produce enzyme such as ACC-deaminase (BAL et al., 2013), improve nutrients uptake (GIONGO et al., 2013), and, allowed improvements in biomass production (NASCENTE et al., 2017a; NASCENTE et al., 2017b). As examples of indirect effects of PGPR, we can show antagonistic mechanisms against phytopathogens and plant parasitic nematodes, production of antagonist compounds and parasitism, and also improving defense system of host plants (BABALOLA, 2010; Matilla et al., 2010).

Due to benefits provided to plant development, use of multifunctional microorganism in agricultural systems has attracted the attention of farmers and technicians. This is because there is an increase in the resistance to pesticides by the pest and pathogens, besides reduction in the resistance of pest and pathogens by the new cultivars. Furthermore, there are some good results showing the potential of the use of multifunctional microorganisms in the agriculture, and there is a claim by the society for the production of safe food without pesticides.

In addition, some fungi species, as Trichoderma asperellum, can be used as a growth promoter microorganism and in the biological control of diseases (DONI et al., 2014; BROTMAN et al., 2010). Species of genera Trichoderma are one of the most studied microorganisms for use in agricultural systems worldwide. Trichoderma species are found in several soils types and act against phytopathogens by different mechanisms, such as, antibiosis, cell wall degrading enzymes production, mycoparasitism, nutrient and substrate competition, plant growth promoting and, also can induce plant resistance against some pathogens (HARMAN et al., 2004; SHORESH et al., 2005; VITERBO et al., 2005; PERAZZOLLI et al., 2008; VINALE et al., 2008; SOUSA et al., 2018).

There are evidences that multifunctional microorganisms can act in a different way in different species, and also in cultivars of the same 
species (MIETHLING et al., 2000; MENDES et al., 2018). In this sense, multifunctional microorganisms sampled in upland rice rhizosphere (FILIPPI et al., 2011; FRANÇA et al., 2015) could have or not beneficial effect in lowland rice cultivars. Thus, there is a need of research to identify those associations, among diverse multifunctional microorganisms and several crops.

Even with many evidences that multifunctional microorganisms allow better plant development in agricultural crops, still there are few studies about the use of them in irrigated rice. Therefore, this work had the objective to study the effect of types and ways of microorganisms application in tropical lowland rice production, evaluated by biomass production and gas exchange.

\section{Material and Methods}

Experiment was done in controlled conditions (greenhouse) at the Embrapa Rice and Beans research center, Santo Antônio de Goiás, GO, Brazil, between June and September of 2017. It was used soil from arable layer $(0-0.20 \mathrm{~m})$ of a kaolinitic, thermic Typic Haplorthox (SANTOS et al., 2018). Soil had 377, 260 and $363 \mathrm{~g} \mathrm{~kg}^{-1}$ of sand, silt and clay, respectively. It was determined the chemical characteristics of the soil using methods proposed by Donagema et al. (2011). The results were: $\mathrm{pH}\left(\mathrm{H}_{2} \mathrm{O}\right)=6.1 ; \mathrm{Ca}^{2+}=$ $78.4 \mathrm{mmol}_{\mathrm{c}} \mathrm{dm}^{3-1} ; \mathrm{Mg}^{2+}=20.9 \mathrm{mmol}_{\mathrm{c}} \mathrm{dm}^{3-1} ; \mathrm{H}^{+}+$ $\mathrm{Al}^{3+}=12 \mathrm{mmol}_{\mathrm{c}} \mathrm{dm}^{3-1} ; \mathrm{P}=35.9 \mathrm{mg} \mathrm{dm} \mathrm{dm}^{3-1} ; \mathrm{K}^{+}=203$ $\mathrm{mg} \mathrm{dm}{ }^{3-1} ; \mathrm{Cu}^{2+}=2.4 \mathrm{mg} \mathrm{dm}^{3-1} ; \mathrm{Zn}^{2+}=2.9 \mathrm{mg} \mathrm{dm}{ }^{3-}$ ${ }^{1} ; \mathrm{Fe}^{3+}=39 \mathrm{mg} \mathrm{dm}^{3-1} ; \mathrm{Mn}^{2+}=28 \mathrm{mg} \mathrm{dm}^{3-1}$ and soil organic matter $=24.7 \mathrm{~g} \mathrm{~kg}^{-1}$.

Approximately 20 days before sowing the cultivar BRS A702 CL of lowland rice, pots of $7 \mathrm{~kg}$ capacity were completely filled with the soil and fertilized with $70 \mathrm{mg} \mathrm{dm}^{3-1}$ of $\mathrm{N}$ (urea), $400 \mathrm{mg}$ $\mathrm{dm}^{3-1}$ de $\mathrm{P}_{2} \mathrm{O}_{5}$ (simple superphosphate) and 200 $\mathrm{mg} \mathrm{dm} \mathrm{de}^{3-1} \mathrm{O}$ (potassium chloride). During all assay, the moisture of soil was determined daily, to keep soil saturated until the end of the vegetative stage (flag leaf formation on the main stem) and after this, water was kept at $4 \mathrm{~cm}$ above the ground until trial harvesting.

Trial design was in a completely randomized, in factorial scheme $7 \times 3+1$, with four replications. Treatments were composed by the combination of seven multifunctional microorganisms: Bacillus sp. (BRM32109 e
BRM32110); Pseudomonas fluorescens (BRM32111); Pseudomonas sp. (BRM32112); Burkholderia pyrrocinia (BRM32113); Serratia sp. (BRM32114) and Trichoderma asperellum pool (UFRA.T06 + UFRA.T09 + UFRA.T12 + UFRA.T52), with three application ways: 1. microbiolized seed (s); 2 . microbiolized seed + soil drenched with microorganism at eight and 15 days after lowland rice sowing (DAS) (ss) and 3 . microbiolized seed + microorganism spray plant at eight and 15 DAS (sp). Besides, we used a control treatment, with a water solution without microorganism.

Rhizobacteria BRM32109; BRM32110; BRM32111; BRM32112; BRM32113; BRM32114 belongs to the collection of microorganism of Embrapa Rice and Beans and, the Trichoderma asperellum pool (isolate UFRA.T06, UFRA.T09, UFRA.T12, e UFRA.T52) is part of fungi collection of Federal Rural University of Amazon. As for the biochemical characteristics and taxonomy classification of rhizobacteria, it is available in Nascente et al. (2017a) and for Trichoderma isolates in Silva et al. (2011).

Microorganism suspension was performed in the way of direct jet at eight and 15 DAS. For this, it was used a manual backpack sprayer with constant pressure of $\mathrm{CO}_{2}$, with a conical nozzle type (TX-VS2), using an amount of around $100 \mathrm{~L} \mathrm{ha}^{-1}$. Each rhizobacteria solution was prepared in liquid medium (nutrient broth), from culture that has been growing on solid medium 523 (KADO; HESKETT, 1970), for 24 hours in 28 oC under constant shaking. Concentration of each suspension was set in a spectrophotometer at an absorbance of 0.5 , wavelength $540 \mathrm{~nm}$, corresponding to $1 \times 10^{8}$ colony forming units (CFU) per $\mathrm{mL}$. Rice seeds were immersed in microorganisms suspensions according each treatment. In control treatment rice seeds were immersed in water. Seeds of all treatments stayed immersed for a period of 24 hours and 25 ㅇ $\mathrm{C}$ temperatures under constant shaking, following methodology proposed by Nascente et al. (2017b).

In the fungi $T$. asperellum pool, it was multiplied and preserved in crushed rice leaves. Therefore, $0.5 \mathrm{~g}$ of each isolate was weighed and $6.7 \mathrm{~mL}$ of white glue solution (1\%) was prepared for each $200 \mathrm{~g}$ of rice seeds. After this, all materials were put in a plastic bag and mixed with the isolates, inducing all the irrigated rice 
seeds according to the methodology proposed by Filippi et al. (2011).

It was sown 15 tropical lowland rice seeds per pot of the genotype BRS A702 CL. Emergence of the plants occurred seven days after sowing and thinned was done 15 days after emergency (DAE) and kept three plants per pot. Topdressing fertilization (two grams of $\left(\mathrm{NH}_{4}\right)_{2} \mathrm{SO}_{4}$ and one gram of $\mathrm{KCl}$ ) was done at the beginning of the rice tillering stage (15 DAE). At $26 \mathrm{DAE}$, it was done the second topdressing fertilization (two grams of $\mathrm{KCl}$ ). Weed control was carried out manually, together with the plants thinning (15 DAE) and there was no need to control pests and diseases.

It was measured leafs width $(\mathrm{cm})$ and gas exchange: photosynthetic rate (A) $\left(\mu \mathrm{mol} \mathrm{CO}_{2} \mathrm{~m}^{-2}\right.$

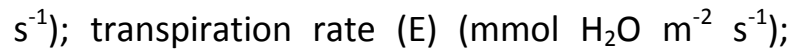

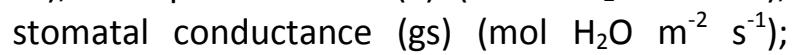
internal $\mathrm{CO}_{2}$ concentration $(\mathrm{Ci})\left(\mu \mathrm{mol} \mathrm{mol}^{-1}\right)$ and leaf temperature (Tleaf) $\left({ }^{\circ} \mathrm{C}\right)$. For this, we used a portable gas meter in the infrared region IRGA (LCpro+, ADC BioScientific). Instantaneous carboxylation efficiency (ICE) was calculated as the ratio of $A$ to $\left.\mathrm{Ci}\left[\left(\mu \mathrm{mol} \mathrm{m}{ }^{-2} \mathrm{~s}^{-1}\right)(\mu \mathrm{mol} \mathrm{mol})^{-1}\right)^{-1}\right]$ (SILVA et al., 2013). The readings were taken between $08 \mathrm{~h} 30$ and $10 \mathrm{~h} 30 \mathrm{AM}$ at 48 DAE (V6 stage) and 96 DAE (R3 stage). Samples were taken in the middle third of the first fully expanded leaf (top to base) during the two evaluation periods. The equipment was set to use concentrations of $370-400 \mathrm{~mol} \mathrm{~mol}^{-1} \mathrm{CO}_{2}$ in the air, which is the reference condition used in the IRGA photosynthesis chamber. The photon flux density photosynthetic active (PPFD) used was $1200 \mu \mathrm{mol}$ [quanta] $\mathrm{m}^{-2} \mathrm{~s}^{-1}$. The minimum equilibration time set for performing the reading was two minutes. Shoots of rice plants were collected at 99 DAE (R3 stage), when $50 \%$ of lowland rice plants were in full flower stage. Thus, in each treatment, the plants were dried in oven 65 ㅇ $\mathrm{C}$ until constant weight and weighed to determine dry matter shoot biomass.

Data were submitted to analyses of variance and, when detected significance, means were compared by LSD test $(p \leq 0.05)$. Besides, we compared treatments with the control (no microorganisms) by Dunnett test at the significance level of 0.05 . It was used the SAS statistical package.

\section{Results and Discussion}

There was difference for transpiration rate (E) and instantaneous carboxylation efficiency (ICE) in irrigated rice plants inoculated by multifunctional microorganisms (Table 1). Lowland rice plants treated with BRM32109 followed by BRM32110, BRM32112, BRM32114 and $T$. asperellum pool presented highest values of E. Multifunctional microorganisms BRM32109 followed by BRM32111, BRM32112, BRM32114 and $T$. asperellum pool provided highest values of ICE in irrigated rice plants. BRM32109, BRM32114 and $T$. asperellum pool provided significant increases in ICE from rice plants and differed from plants of the control treatment. 
Table 1. Physiological attributes: photosynthesis (A) ( $\left.\mu \mathrm{mol} \mathrm{CO}_{2} \mathrm{~m}^{-2} \mathrm{~s}^{-1}\right)$, transpiration (E) $\left(\mathrm{H}_{2} \mathrm{O} \mathrm{m} \mathrm{m}^{-2} \mathrm{~s}^{-1}\right)$, stomatal conductance (gs) ( $\mathrm{mol} \mathrm{H}_{2} \mathrm{O} \mathrm{m}^{-2} \mathrm{~s}^{-1}$ ), internal $\mathrm{CO}_{2}$ concentration $(\mathrm{Ci})\left(\mu \mathrm{mol} \mathrm{mol}^{-1}\right)$, leaf temperature

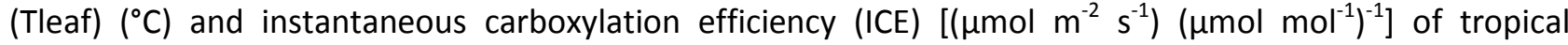
lowland rice plants, cultivar BRS A702 CL, microbiolized with different types and ways of multifunctional microorganisms application, in two evaluation times, 48 DAE (V6 stage) and 96 DAE (R3 stage).

\begin{tabular}{lllllll}
\hline Microorganism & $\mathrm{A}$ & $\mathrm{E}$ & $\mathrm{gs}$ & $\mathrm{Ci}$ & Tleaf & ICE \\
\hline BRM32109 & 16.96 & $5.86 \mathrm{a}^{+}$ & 0.245 & 224 & 31.63 & $0.077 \mathrm{a}^{*}$ \\
BRM32110 & 15.58 & $5.62 \mathrm{ab}$ & 0.235 & 233 & 31.66 & $0.067 \mathrm{~b}$ \\
BRM32111 & 15.81 & $5.32 \mathrm{~b}$ & 0.224 & 230 & 31.53 & $0.068 \mathrm{ab}$ \\
BRM32112 & 15.52 & $5.38 \mathrm{ab}$ & 0.217 & 226 & 31.60 & $0.069 \mathrm{ab}$ \\
BRM32113 & 15.88 & $5.29 \mathrm{~b}$ & 0.217 & 234 & 31.38 & $0.065 \mathrm{~b}$ \\
BRM32114 & 16.18 & $5.66 \mathrm{ab}$ & 0.237 & 228 & 31.62 & $0.071 \mathrm{ab}^{*}$ \\
T. asperellum pool & 16.37 & $5.59 \mathrm{ab}$ & 0.233 & 224 & 31.66 & $0.074 \mathrm{ab}^{*}$ \\
\hline Control & 14.87 & 5.28 & 0.217 & 238 & 31.33 & 0.060 \\
\hline Application form & & & & & & \\
Seed (s) & 16.51 & 5.48 & 0.230 & 230 & 31.38 & 0.071 \\
Seed + soil (ss) & 15.75 & 5.39 & 0.220 & 224 & 31.67 & 0.070 \\
Seed + plant (sp) & 15.86 & 5.72 & 0.238 & 231 & 31.70 & 0.069 \\
\hline Evaluation times & & & & & & \\
Vegetative stage & 16.26 & $4.78 \mathrm{~b}$ & $0.244 \mathrm{a}$ & $243 \mathrm{a}$ & $29.01 \mathrm{~b}$ & $0.066 \mathrm{~b}$ \\
Reproductive stage & 15.82 & $6.29 \mathrm{a}$ & $0.215 \mathrm{~b}$ & $214 \mathrm{~b}$ & $34.15 \mathrm{a}$ & $0.074 \mathrm{a}$ \\
\hline CV (\%) & 16.00 & 17.19 & 26.26 & 11.22 & 7.37 & 22.28 \\
\hline
\end{tabular}

${ }^{+}$Means followed by the same letter do not differ by LSD test at $p \leq 0.05$. Means followed by the asterisk differ from the control treatment (without microorganism) by Dunnett test at $p \leq 0.05$.

Measurement of carboxylation efficiency is important to estimate Rubisco activity. Therefore, we can infer that lowland rice plants that presented higher ICE is because present higher ability to overcome the limitation in the $\mathrm{CO}_{2}$ diffusion through the stomatal and mesophyll and, hence, greater capacity to fix $\mathrm{CO}_{2}$ (GALMÉS et al., 2011; COUSINS et al., 2020). This evaluation is a tool to determine the adaptation and response of plants to environment, once the increase in plant growth (consequently increase in yield) could be connected to the improvement of the biochemical activity of photosynthesis, in this case, potentiated by biotic factors as the introduction of the multifunctional microorganisms tested.

There were also significant differences between evaluation time (V6 and R3 physiological stage) in E, stomatal conductance (gs), internal $\mathrm{CO}_{2}$ concentration $(\mathrm{Ci})$ and leaf temperature (Tleaf) of lowland rice plants (Table 1). Higher Tleaf and, hence, higher E and ICE was affected and related to the high ambient temperature of the greenhouse at reproductive stage of irrigated rice plants.

Autotrophic species use $\mathrm{CO}_{2}$ as substrate for the photosynthetic process. This gas enters the plant through stomatal chamber. On the other hand, transpiration rate indicates the loss of $\mathrm{H}_{2} \mathrm{O}$ in the vapor form, from the plant to the atmosphere. Both gases pass through stomatal cell. The stomatal must be open to absorb $\mathrm{CO}_{2}$, which allows the loss of $\mathrm{H}_{2} \mathrm{O}$ (BUCKLEY, 2019). Our lowland rice was cultivated under flooded, therefore, these plants did not need to close the stomatal to keep the turgidity of cells. Therefore, it is better for this crop to exchange water for photosynthesis product, essentials for crop growth, once the water supply is plentiful (TAIZ et al., 2017).

Multifunctional microorganisms provided significant effect on dry shoot biomass production of lowland rice (Table 2). Rhizobateria BRM32114 (Serratia sp.) provided highest plants development, with values of $61.24 \mathrm{~g}$ of dry biomass and differed from plants of the control treatment. Rhizobacteria BRM32111 (Pseudomonas fluorescens); BRM32113 (Burkholderia pyrrocinia) and fungi T. asperellum pool also provided irrigated rice biomass increase, with values of 58.73; 56.89 and $56.62 \mathrm{~g}$ of dry shoots, respectively. 
Table 2. Dry shoot biomass production of tropical lowland rice, cultivar BRS A702 CL, treated with different types and forms of multifunctional microorganism application.

\begin{tabular}{lc}
\hline Microorganism & Dry shoot biomass (g) \\
\hline BRM32114 & $61.24 \mathrm{a}^{+*}$ \\
BRM32111 & $58.73 \mathrm{ab}$ \\
BRM32113 & $56.89 \mathrm{abc}$ \\
T. asperellum pool & $56.62 \mathrm{abc}$ \\
BRM32112 & $53.59 \mathrm{bcd}$ \\
BRM32110 & $51.21 \mathrm{~cd}$ \\
BRM32109 & $48.31 \mathrm{~d}$ \\
\hline Control & 47.94 \\
\hline Application form & \\
Seed (s) & 56.11 \\
Seed + soil (ss) & 56.53 \\
Seed + plant (sp) & 53.04 \\
\hline CV (\%) & 15.22 \\
\hline
\end{tabular}

${ }^{+}$Means followed by the same letter do not differ by LSD test at $p \leq 0.05$. Means followed by the asterisk differ from the control treatment (without microorganism) by Dunnett test at $p \leq 0.05$.

The beneficial effects of the use of multifunctional microorganisms in rice plants are also showed by other authors. For example, Sperandio et al. (2017) tested rhizobacterias BRM32114 and BRM32109 (Bacillus sp.) with the control plants (no microorganism), in upland rice plants (cultivar BRS Primavera) and reported that rhizobacteria BRM32114 was the most effective to provide improvement of dry shoot biomass production and in suppression of leaf blast pathogen (Magnaporthe oryzae). Souza (2014) showed that $T$. asperellum provided, in average, $45.6 \%$ more biomass accumulation in rice plants (cultivar BRS Primavera) than control treatment (plants without microorganism). This same author observed significant reduction of 96 and $67 \%$ of leaf blast with use of the rhizobacteria BRM32113 and BRM32111, respectively. Rêgo et al. (2014) carried out an experiment to determine root architecture and observed that rice seeds (cultivar BRS Primavera) treated with the fungi $T$. asperellum pool, rhizobacteria BRM32113 and rhizobacteria BRM32111 stimulate a production of rice seedlings with greater root length, cortex expansion (increase of $2 \%$ ) in the aerenchyma spaces, besides of increase of diameter and root volume. In this same sense, Sousa et al. (2019) showed that BRM32110 (Bacillus sp.) and BRM32112 (Pseudomonas sp.) provided, in average, increase of $25.7 \%$ of seedlings root length (cultivar BRS Catiana). In different ways, these researches corroborate our results and show that using multifunctional microorganism is a good strategy to improve rice development as verified in our experiment. Suppression of disease, increase in shoot dry biomass and root length is some effects of action of these microorganisms.

The rhizobacteria and fungi tested in our research were sampled from upland rice rhizosphere (MIETHLING et al., 2000). However, these multifunctional microorganisms provided significant improvement in gas exchange and biomass production in rice plants cultivar BRS A702 CL. Nascente et al. (2017b) also reported that the lowland rice cultivar (BRS Catiana) had higher biomass production when the plants were inoculated with the rhizobacteria BRM32109 (Bacillus sp.), in relation to the plants from control treatment. However, it is important to mention that it is necessary more researches with the use of multifunctional microorganisms, because of this singular interaction between plant-microorganism, once even in cultivars of the same crop specie, we could see differences in the effect of the multifunctional microorganism in each cultivar. For example, in the BRS Catiana cultivar, rhizobacteria BRM32109 allowed better rice yield (NASCENTE et al., 2017b), and, BRM32110 and BRM32112 (Bacillus sp. and Pseudomonas fluorescens respectively) provided most development of seedlings root length (SOUSA et al., 2019). On the other hand, in our trial, which we tested the lowland rice cultivar 
BRS A702 CL, rhizobacteria BRM32114 (Serratia sp.) provided highest plant development. These results are corroborated by the report of Mendes et al. (2018), which informed that microorganisms could have different effects in cultivars of the same species.
We could see that to dry shoot biomass accumulation in irrigated rice plants there was significant interaction among microorganisms and application way (Table 3).

Table 3. Effect of types and ways of multifunctional microorganisms application on tropical lowland dry biomass production, cultivar BRS A702 CL.

\begin{tabular}{|c|c|c|c|c|}
\hline Factors & Seed (s) & Seed and soil (ss) & $\begin{array}{l}\text { Seed and plant } \\
\text { (sp) }\end{array}$ & CV \\
\hline Microorganism & \multicolumn{4}{|c|}{ Dry shoot biomass (grams) } \\
\hline BRM32111 & $65.51 \mathrm{a} \mathrm{A}^{+}$ & $59.91 \mathrm{abc} A B$ & $50.76 \mathrm{ab} \mathrm{B}$ & 12.73 \\
\hline BRM32113 & 65.35 ab A & $62.96 \mathrm{ab} \mathrm{A}$ & $42.36 \mathrm{~b} \mathrm{~B}$ & 17.51 \\
\hline T. asperellum pool & $57.13 a b c A$ & 54.57 bc A & 58.17 a $\mathrm{A}$ & 14.00 \\
\hline BRM32114 & $55.01 \mathrm{abc} A$ & 68.04 a $A$ & 60.68 a $A$ & 20.66 \\
\hline BRM32112 & $52.14 \mathrm{bc} \mathrm{A}$ & 53.14 bc A & 55.49 a $\mathrm{A}$ & 14.25 \\
\hline BRM32110 & 51.53 c A & $49.24 \mathrm{c} \mathrm{A}$ & $52.86 \mathrm{ab} \mathrm{A}$ & 10.79 \\
\hline BRM32109 & $46.13 \mathrm{c} \mathrm{A}$ & 47.85 c A & $50.95 \mathrm{ab} \mathrm{A}$ & 10.64 \\
\hline $\mathrm{CV}$ & 15.97 & 15.94 & 14.96 & - \\
\hline
\end{tabular}

${ }^{+}$Means followed by the same letter, lowercase in the column or upper case in the line, do not differ by LSD test at $p \leq 0.05$. CV is coefficient of variation.

In microorganism application by seeds (s), there was higher lowland rice biomass in plants microbiolized with the rhizobacteria BRM32111, BRM32113, BRM32114 and fungi T. asperellum pool. In the application by (s) and seed-soil (ss), better results in rice plants were achieved in the rhizobacteria BRM32111, BRM32113 and BRM32114. In the microorganisms application by seed-plant (sp) it was observed that rhizobacteria BRM32113 provided smallest lowland rice biomass. Therefore, our results allow inferring that microbiolized seeds was the best way to put the microorganism in the irrigated rice cultivar BRS A702 CL, once it provide highest values inrice plants and did not differ from other treatments, and because is the cheapest and easiest method to the farmer, in comparison to the other methods tested, and it is in agreement of previous results (NASCENTE et al., 2017a; NASCENTE et al., 2017b).

\section{Conclusions}

Seed microbiolization was the most effective form to provide lowland rice shoot biomass increases.

Irrigated rice plants microbiolized with the multifunctional microorganisms BRM32109, BRM32114 and T. asperellum pool provided highest instantaneous carboxylation efficiency, compared to the plants of the control treatment.

BRM32114 followed by BRM32111, BRM32112 and T. asperellum pool provided increases in dry shoot biomass in tropical lowland rice.

\section{Aknowledgements}

To Embrapa (Brazilian Agricultural Research Corporation), for supporting this research and, to CNPq (National Council of Scientific and Technological Development), for an award for excellence in research of the second and third author.

\section{References}

BABALOLA, O. O. Beneficial bacteria of agricultural importance. Biotechnology Letters, v. 32, n. 11, p. 1559-1570, 2010. https://doi.org/10.1007/s10529-010-0347-0

BAL, H. B.; NAYAK, L.; DAS, S.; ADHYA, T. K. Isolation of $A C C$ deaminase producing PGPR from rice rhizosphere and evaluating their plant growth promoting activity under salt stress. Plant and Soil, v. 366, n. 1-2, p. 93-105, 2013. https://doi.org/10.1007/s11104-012-1402-5 
BORÉM, A.; RANGEL, P. H. N. Arroz do plantio à colheita. Viçosa: Editora UFV, 2015.

BROTMAN, Y.; GUPTA, K. J.; VITERBO, A. Trichoderma. Current Biology, v. 20, n. 9, p. 390391, 2012.

https://doi.org/10.1016/i.cub.2010.02.042

BUCKLEY, T. N. How do stomata respond to water status?. New Phytologist, v. 224, n. 1, p. 21-36, 2019. https://doi.org/10.1111/nph.15899

COMPANHIA NACIONAL DE ABASTECIMENTO (CONAB). Acompanhamento da safra brasileira de grãos. Brasília: CONAB, 2021.

COUSINS, A. B.; MULLENDORE, D. L.; SONAWANE, B. V. Recent developments in mesophyll conductance in C3, C4, and crassulacean acid metabolism plants. The Plant Journal, v. 101, n. 4, p. 816-830, 2020.

https://doi.org/10.1111/tpj.14664

DONAGEMA, G. K.; CAMPOS, D. V. B.; CALDERANO, S. B.; TEIXEIRA, W. G.; VIANA, J. H. $M$. Manual de métodos de análise de solo. Rio de Janeiro: Embrapa Solos, 2011.

DONI, F.; ISAHAK, A.; ZAIN, C. R. C. M.; YUSOFF, W. M. W. Physiological and growth response of rice plants (Oryza sativa L.) to Trichoderma spp. inoculants. AMB Express, v. 4, n. 1, p. 285-290, 2014. https://doi.org/10.1186/s13568-014-0045$\underline{8}$

FILIPPI, M. C. C.; SILVA, G. B.; SILVA-LOBO, V. L.; CÔRTES, M. V. C. B.; MORAES, A. J. G.; PRABHU, A. S. Leaf blast (Magnaporthe oryzae) suppression and growth promotion by rhizobacteria on aerobic rice in Brazil. Biological Control, v. 58, n. 2, p. 160-166, 2011.

https://doi.org/10.1016/i.biocontrol.2011.04.016

FOOD AND AGRICULTURE ORGANIZATION OF THE UNITED NATIONS (FAOSTAT). Production quantities of Rice, paddy by country: average 1994 - 2019. Roma: FAO, 2021. Disponível em: http://www.fao.org/faostat/en/\#data/QC/visuali ze. Acesso: 26 fev. 2021.

FRANÇA, S. K. S.; CARDOSO, A. F.; LUSTOSA, D. C.; RAMOS, E. M. L. S.; FILIPPI, M. C. C.; SILVA, G. B.
Biocontrol of sheath blight by Trichoderma asperellum in tropical lowland rice. Agronomy for Sustainable Development, v. 35, n. 1, p. 317-324, 2015. https://doi.org/10.1007/s13593-014-0244$\underline{3}$

GALMÉs, J.; RIBAS-CARBÓ, M.; MEDRANO, H.; FLEXAS, J. Rubisco activity in Mediterranean species is regulated by the chloroplastic $\mathrm{CO}_{2}$ concentration under water stress. Journal of Experimental Botany, v. 62, n. 2, p. 653-665, 2011. https://doi.org/10.1093/jxb/erq303

GHOLAMALIZADEH, R.; KHODAKARAMIAN, G.; EBADI, A. A. Assessment of rice associated bacterial ability to enhance rice seed germination and rice growth promotion. Brazilian Archives of Biology and Technology, v. 60, n. 1, p. 1-13, $2017 . \quad$ https://doi.org/10.1590/1678-43242017160410

GIONGO, A.; BENEDUZI, A.; GANO, K.; VARGAS, L. K.; UTZ, L.; PASSAGLIA, L. M. P. Characterization of plant growth-promoting bacteria inhabiting Vriesea gigantea Gaud. and Tillandsia aeranthos (Loiseleur) L.B. Smith (Bromeliaceae). Biota Neotropica, v. 13, n. 3, p. 80-85, 2013.

https://doi.org/10.1590/S1676$\underline{06032013000300010}$

HARMAN, G. E.; HOWELL, C. R.; VITERBO, A.; CHET, I.; LORITO, M. Trichoderma species opportunistic, avirulent plant symbionts. Nature Reviews Microbiology, v. 2, n. 1, p. 43-56, 2004. https://doi.org/10.1038/nrmicro797

KADO, C. J.; HESKETT, M. G. Selective media for isolation of Agrobacterium, Corynebacterium, Erwinia, Pseudomonas and Xanthomonas. Phytopathology, v. 60, n. 6, p. 969-976, 1970. https://doi.org/10.1094/Phyto-60-969

KLOEPPER, J. W.; SCHROTH, M. N. Plant growthpromoting rhizobacteria on radishes. Proceedings of the 4th International Conference on Plant Pathogenic Bacteria. France: Anais GilbertClarey, 1978.

MATILLA, M. A.; RAMOS, J. L.; BAKKER, P. A. H. M.; DOORNBOS, R.; BADRI, D. V.; VIVANCO, J. M.; RAMOS-GONZÁLES, M. I. Pseudomonas putida KT2440 causes induced systemic resistance and 
changes in Arabidopsis root exudation. Environmental Microbiology Reports, v. 2, n. 3, p. 381-388, 2010. https://doi.org/10.1111/j.17582229.2009.00091.x

MENDES, L. W.; RAAIJMAKERS, J. M.; HOLLANDER, M.; MENDES, R.; TSAI, S. M. Influence of resistance breeding in common bean on rhizosphere microbiome composition and function. ISME Journal, v. 12, n. 1, p. 212-224, 2018. https://doi.org/10.1038/ismej.2017.158

MIETHLING, R.; WIELAND, G.; BACKHAUS, H.; TEBBE, C. C. Variation of microbial rhizosphere communities in response to crop species, soil origin, and inoculation with Sinorhizobium meliloti L33. Microbial Ecology, v. 41, n. 1, p. 4356, 2000.

https://doi.org/10.1007/s002480000021

NASCENTE, A. S. N.; FILIPPI, M. C. C.; LANNA, A. C.; SOUZA, A. C. A.; LOBO, V. L. S.; SILVA, G. B. Biomass, gas exchange, and nutrient contents in upland rice plants affected by application forms of microorganism growth promoters. Environmental Science and Pollution Research, v. 24, n. 3, p. 2956-2965, 2017a. https://doi.org/10.1007/s11356-016-8013-2

NASCENTE, A. S.; FILIPPI, M. C. C.; LANNA, A. C.; SOUSA, T. P.; SOUZA, A. C. A.; LOBO, V. L. S.; SILVA, G. B. Effects of beneficial microorganisms on lowland rice development. Environmental Science and Pollution Research, v. 24, n. 32, p. 25233-25242, 2017b.

https://doi.org/10.1007/s11356-017-0212-y

PERAZZOLLI, M.; DAGOSTIN, S.; FERRARI, A.; ELAD, Y.; PERTOT, I. Induction of systemic resistance against Plasmopara viticola in grapevine by Trichoderma harzianum T39 and benzothiadizole. Biological Control, v. 47, n. 2, p. 228-234, 2008.

https://doi.org/10.1016/j.biocontrol.2008.08.008

RÊGO, M. C. F.; ILKIU-BORGES, F.; FILIPPI, M. C. C.; GONÇALVES, L. A.; SILVA, G. B. Morphoanatomical and Biochemical Changes in the Roots of Rice Plants Induced by Plant GrowthPromoting Microorganisms. Journal of Botany, v. 2014, n. 1, p. 1-10, 2014.

https://doi.org/10.1155/2014/818797
SAHA, L.; BAUDDH, K. Sustainable Agriculture Approaches for Enhanced Crop Productivity, Better Soil Health, and Improve Ecosystem Services. Ecological and Practical Applications for Sustainable Agriculture. Singapore: Springer, 2020. https://doi.org/10.1007/978-981-15-337231

SANTOS, H. G.; JACOMINE, P. K. T.; ANJOS, L. H. C.; OLIVEIRA, V. A.; LUMBRERAS, J. F.; COELHO, M. R.; ALMEIDA, J. A.; ARAUJO FILHO, J. C.; OLIVEIRA, J. B.; CUNHA, T. J. F. Sistema brasileiro de classificação de solos. Rio de Janeiro: Centro Nacional de Pesquisa de Solos, 2018.

SEN, S.; CHAKRABORTY, R.; KALITA, P. Rice - not just a staple food: A comprehensive review on its phytochemicals and therapeutic potential. Trends in food science and technology, v. 97, n. 1, p. 265-285, 2020.

https://doi.org/10.1016/j.tifs.2020.01.022

SHORESH, M.; YEDIDIA, I.; CHET, I. Involvement of jasmonic acid/ethylene signaling pathway in the systemic resistance induced in cucumber by Trichoderma asperellum T203. Phytopathology, v. 95, n. 1, p. 76-84, 2005.

https://doi.org/10.1094/PHYTO-95-0076

SILVA, M. A.; JIFON, J. L.; SANTOS, C. M.; JADOSKI, C. J.; SILVA, J. A. C. Photosynthetic Capacity and Water Use Efficiency in Sugarcane Genotypes Subject to Water Deficit During Early Growth Phase. Brazilian Archives of Biology and Technology, v. 56, n. 5, p. 735-748, 2013.

https://doi.org/10.1590/S1516$\underline{89132013000500004}$

SILVA, V. N.; GUZZO, S. D.; LUCON, C. M. M.; HARAKAVA, R. Promoção de crescimento e indução de resistência à antracnose por Trichoderma spp. em pepineiro. Pesquisa Agropecuária Brasileira, v. 46, n. 12, p. 16091618, 2011. https://doi.org/10.1590/S0100204X2011001200005

SOUSA, I. M.; NASCENTE, A. S.; FILIPPI, M. C. C. Bactérias promotoras do crescimento radicular em plântulas de dois cultivares de arroz irrigado por inundação. Colloquium agrariae, v. 15, n. 2, p. 140-145, 2019.

https://doi.org/10.5747/ca.2019.v15.n1.a293 
SOUSA, T. P.; SOUZA, A. C. A.; FILIPPI, M. C. C.; LANNA, A. C.; CORTÊS, M. V.; PINHEIRO, H. A.; SILVA, G. B. Bioagents and silicon promoting fast early upland rice growth. Environmental Science and Pollution Research, v. 25, n. 4, p. 3657-3668, 2018. https://doi.org/10.1007/s11356-017-0753$\underline{0}$

SOUZA, A. C. A. Silício e bioagentes na supressão da brusone foliar em arroz. 2014. $48 \mathrm{f}$. Dissertação (Mestrado em Agronomia) Universidade Federal de Goiás, Goiânia, 2014.

SPENCE, C.; ALFF, E.; JOHNSON, C.; RAMOS, C.; DONOFRIO, N.; SUNDARESAN, V.; BAIS, H. Natural rice rhizospheric microbes suppress rice blast infections. BMC Plant Biology, v. 14, n. 1, p. 1-17, 2014. https://doi.org/10.1186/1471-2229-14-130

SPERANDIO, E. M.; VALE, H. M. M.; REIS, M. S.; CORTÊS, M. V. C. B.; LANNA, A. C.; FILIPPI, M. C. Evaluation of rhizobacteria in uplant rice in Brazil: growth promotion and interaction of induced defense responses against leaf blast (Magnaporthe oryzae). Acta Physiologiae Plantarum, v. 39, n. 12, p. 258-270, 2017.

https://doi.org/10.1007/s11738-017-2547-x

TAIZ, L.; ZEIGER, E.; MOLLER, I. M.; MURPHY, A. Fisiologia e desenvolvimento vegetal. Porto Alegre: Artmed, 2017.

TIAN, X.; ENGEL, B. A.; QIAN, H.; HUA, E.; SUN, S.; WANG, Y. Will reaching the maximum achievable yield potential meet future global food demand?. Journal of Cleaner Production, v. 294, n. 1, p. 126285, 2021.

https://doi.org/10.1016/i.jclepro.2021.126285

VINALE, F.; SIVASITHAMPARAM, K.; GHISALBERTI, E. L.; MARRA, R.; BARBETTI, M. J.; LI, H.; WOO, S. L.; LORITO, M. A novel role for Trichoderma secondary metabolites in the interactions with plants. Physiological and Molecular Plant Pathology, v. 72, n. 3, p. 80-86, 2008.

https://doi.org/10.1016/i.pmpp.2008.05.005

VITERBO, A.; HAREL, M.; HORWITZ, B. A.; CHET, I.; MUKHERJEE, P. K. Trichoderma mitogen-activated protein kinase signaling is involved in induction of plant systemic resistance. Applied and
Environmental Microbiology, v. 71, n. 10, p. 6241-6246, 2005.

https://doi.org/10.1128/AEM.71.10.6241$\underline{6246.2005}$ 